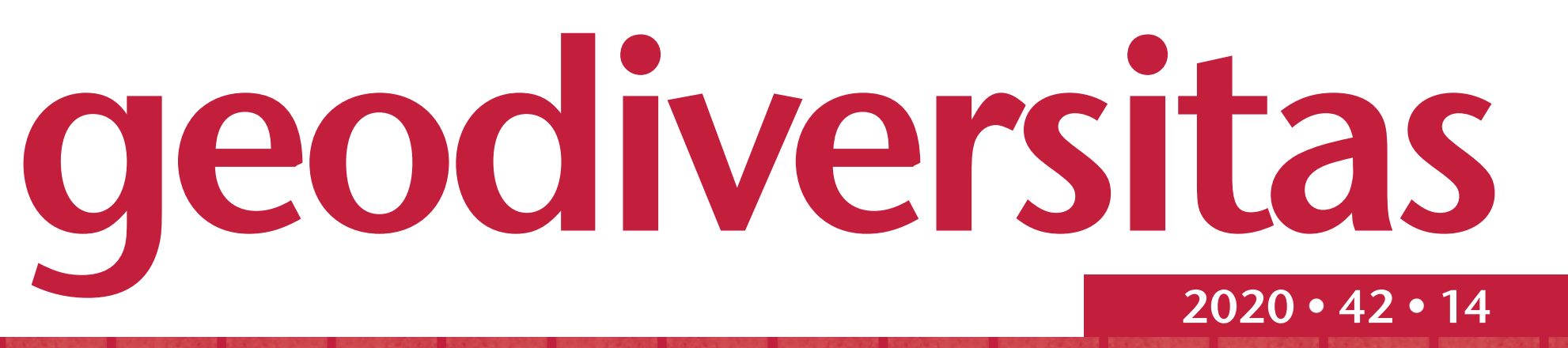

\title{
Juvenile eucladid crinoid from the Middle Devonian of Turkey
}

William I. AUSICH \& M. Cemal GöNCÜOǦLU

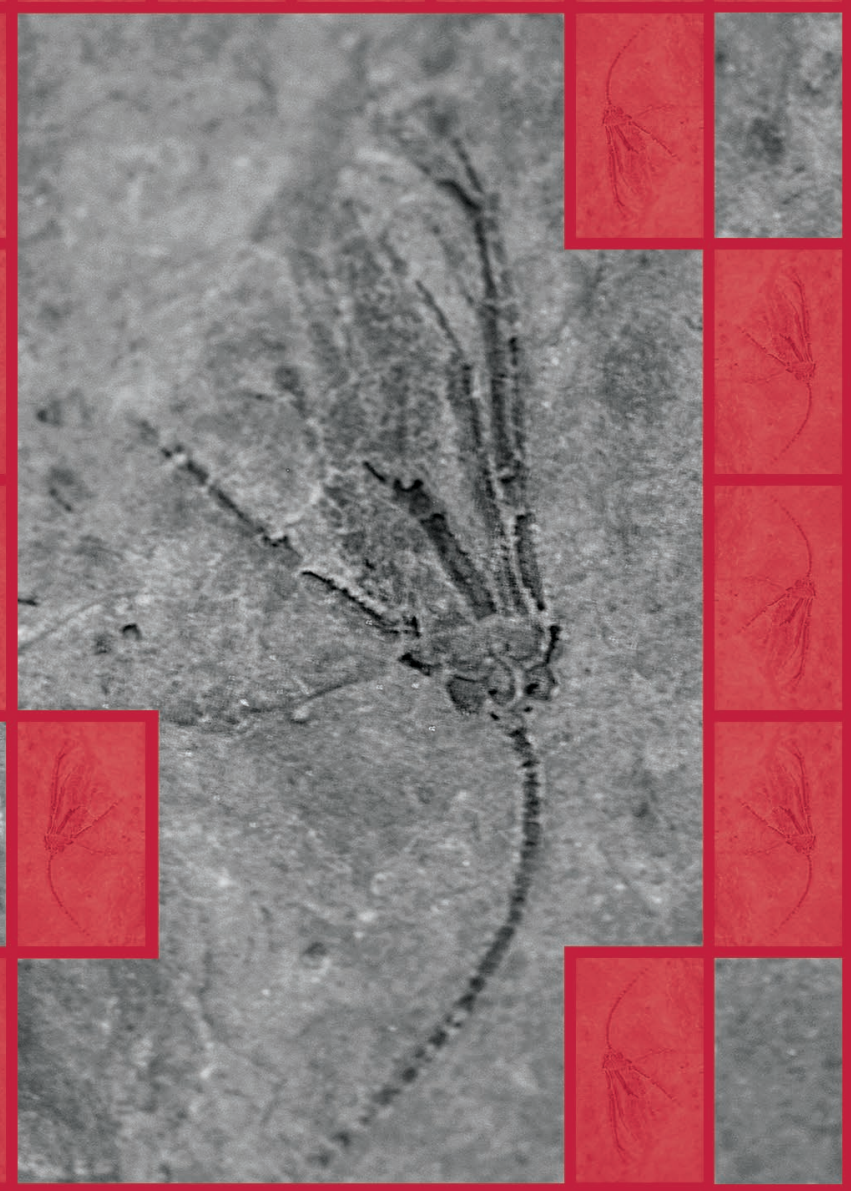


DiRECTEUR de LA PUBLICATION / PUBLICATION DIRECTOR: Bruno David, Président du Muséum national d'Histoire naturelle

RÉdACTEUR EN CHEF / EDITOR-IN-CHIEF: Didier Merle

ASSISTANT DE RÉDACTION / ASSISTANT EDITOR: Emmanuel Côtez (geodiv@mnhn.fr)

Mise en PAGE / PAGE LAYOUt: Anne Mabille, Emmanuel Côtez

COMITÉ SCIENTIFIQUE / SCIENTIFIC BOARD:

Christine Argot (Muséum national d'Histoire naturelle, Paris)

Beatrix Azanza (Museo Nacional de Ciencias Naturales, Madrid)

Raymond L. Bernor (Howard University, Washington DC)

Alain Blieck (chercheur CNRS retraité, Haubourdin)

Henning Blom (Uppsala University)

Jean Broutin (Sorbonne Université, Paris, retraité)

Gaël Clément (Muséum national d'Histoire naturelle, Paris)

Ted Daeschler (Academy of Natural Sciences, Philadelphie)

Bruno David (Muséum national d'Histoire naturelle, Paris)

Gregory D. Edgecombe (The Natural History Museum, Londres)

Ursula Göhlich (Natural History Museum Vienna)

Jin Meng (American Museum of Natural History, New York)

Brigitte Meyer-Berthaud (CIRAD, Montpellier)

Zhu Min (Chinese Academy of Sciences, Pékin)

Isabelle Rouget (Muséum national d'Histoire naturelle, Paris)

Sevket Sen (Muséum national d'Histoire naturelle, Paris, retraité)

Stanislav Štamberg (Museum of Eastern Bohemia, Hradec Králové)

Paul Taylor (The Natural History Museum, Londres, retraité)

COUVERTURE / COVER:

Made from the Figures of the article.

Geodiversitas est indexé dans / Geodiversitas is indexed in:

- Science Citation Index Expanded (SciSearch $\left.{ }^{\circledR}\right)$

- ISI Alerting Services ${ }^{\circledR}$

- Current Contents ${ }^{\circledR}$ / Physical, Chemical, and Earth Sciences ${ }^{\circledR}$

- Scopus ${ }^{\circledR}$

Geodiversitas est distribué en version électronique par / Geodiversitas is distributed electronically by:

- BioOne ${ }^{\circledR}$ (http://www.bioone.org)

Les articles ainsi que les nouveautés nomenclaturales publiés dans Geodiversitas sont référencés par / Articles and nomenclatural novelties published in Geodiversitas are referenced by:

- ZooBank ${ }^{\circledR}$ (http://zoobank.org)

Geodiversitas est une revue en flux continu publiée par les Publications scientifiques du Muséum, Paris Geodiversitas is a fast track journal published by the Museum Science Press, Paris

Les Publications scientifiques du Muséum publient aussi / The Museum Science Press also publish:

Adansonia, Zoosystema, Anthropozoologica, European Journal of Taxonomy, Naturae, Cryptogamie sous-sections Algologie, Bryologie, Mycologie.

Diffusion - Publications scientifiques Muséum national d'Histoire naturelle

CP $41-57$ rue Cuvier F-75231 Paris cedex 05 (France)

Tél. : 33 (0)1407948 05 / Fax: 33 (0)14079 3840

diff.pub@mnhn.fr / http://sciencepress.mnhn.fr

(C) Publications scientifiques du Muséum national d'Histoire naturelle, Paris, 2020

ISSN (imprimé / print): 1280-9659/ ISSN (électronique / electronic): 1638-9395 


\title{
Juvenile eucladid crinoid from the Middle Devonian of Turkey
}

\author{
William I. AUSICH \\ School of Earth Sciences, 155 South Oval Mall, \\ The Ohio State University, Columbus, OH 43210 (United States) \\ ausich.1@osu.edu \\ M. Cemal GÖNCÜOĞLU \\ Department of Geological Engineering, \\ Middle East Technical University, Ankara (Turkey) \\ mcgoncu@metu.edu.tr
}

Submitted on 17 July 2019 | accepted on 18 September 2019 | published on 11 June 2020

KEY WORDS

Crinoid,

Devonian,

Famennian,

Hakkari,

southeastern Turkey.

MOTS CLÉS

Crinoïdes,

Dévonien,

Famennien,

Turquie du Sud-Est.

urn:Isid:zoobank.org:pub:46131EB1-625B-4D9C-977D-D2E96E44312C

Ausich W. I. \& Göncüoğlu M. C. 2020. - Juvenile eucladid crinoid from the Middle Devonian of Turkey. Geodiversitas 42 (14): 215-221. https://doi.org/10.5252/geodiversitas2020v42a14. http://geodiversitas.com/42/14

\section{ABSTRACT}

A microcrinoid-sized eucladid crinoid (Eucladida Wright, 2017) is described from the Yığınlı Formation (Devonian, Famennian) in the Büyük Zap Anticline in the Hakkari region of SE Turkey. Compared to other eucladids of similar size, the Yığınlı Formation specimen is at a quite advanced morphological stage with arms present through at least the secundibrachials. Early post-larval development is a key for understanding homologies among crinoid clades; however Paleozoic crinoids in the microcrinoid range $(\leq 2.0 \mathrm{~mm})$ are very rare. This specimen is either at a very advanced developmental stage for its size, or typical microcrinoids are neotenic.

\section{RÉSUMÉ}

Crinoïdes eucladides juvéniles du Dévonien moyen de Turquie.

Une micro-crinoïde eucladide (Eucladida Wright, 2017) est décrite de la Formation Yı̆̆ınlı (Dévonien, Famennien, anticlinal Büyük Zap, région d'Hakkari, sud-est de la Turquie). Comparé à d'autres eucladides de même taille, ce spécimen est à un stade morphologique un peu plus avancé, avec des bras présents au moins jusqu'aux secundibrachiales. Le développement post-larvaire est une clé pour la compréhension des homologies au sein des clades de crinoïdes. Cependant, les crinoïdes paléozoïques de la taille de celles des micro-crinoïdes $(\leq 2.0 \mathrm{~mm})$ sont très rares. Ce spécimen est soit à un stage de développement très avancé pour sa taille ou bien les micro-crinoïdes typiques sont néoténiques. 


\section{INTRODUCTION}

Confident homology statements are required for robust phylogenetic analyses, but this may be difficult due to disparate adult morphologies. This is especially true among echinoderm clades (Sumrall \& Waters 2012), as well as among major clades of the Crinoidea. Study of early post-larval development provides important data for understanding homologies (e.g., Lane \& Sevastopulo 1982a, b; Sevastopulo \& Lane 1988; Ausich 1996; Wright 2015; Ausich et al. 2020). The early post-larval developmental stages are known for only a very few Paleozoic crinoids, which makes the specimen described here an important discovery despite the fact that it cannot be assigned to a genus or species with certainty.

The first Paleozoic crinoidal remains described from Turkey were based on isolated columnals (Arthaber 1900). Arachnocrinus sarizensis Webster, Yilmaz \& Kozluc, 2008 was the first Paleozoic crinoid described from Turkey based on crown material, but it was based largely on disarticulated material, including isolated brachial plates, a juvenile aboral cup, holdfast, and columnals. Arachnocrinus sarizensis is Middle Devonian in age. In this report, we describe the first nearly complete crinoid known from Paleozoic strata of Turkey. This new specimen is from the uppermost part of the Yığınlı Formation in the Büyük Zap Anticline in the Hakkari region of SE Turkey. It is a eucladid crinoid. Despite being nearly complete, this new specimen is a juvenile individual for which adult characters cannot be determined with certainty, which precludes confident assignment to a genus or species.

\section{GEOLOGICAL FRAMEWORK}

In Anatolia, thick Paleozoic sedimentary successions of northeastern Gondwana-origin crop out in the Istanbul-Zonguldak, Tauride-Anatolide, and the SE Anatolian terranes (Fig. 1A) (Göncüoğlu 1997; Yalçın \& Yılmaz 2010). In the Hakkari province of SE Turkey in the northern promontory of the Arabian microcontinent, more or less complete Paleozoic successions occur in a number of E-W trending anticlines. Between the towns of Hakkari and Cukurca close to the Iraq border, Upper Devonian and lower Carboniferous rocks were reported (Janvier et al. 1984) in the cores of two east-westtrending anticlines, the Büyük Zap Anticline to the north and the smaller Cukurca Anticline to the south (Fig. 1B). The best exposures are along the Zap and Cevizlik rivers cutting through these structures. In the former one, the succession comprises the Cambrian Sadan, Zabuk and Koruk formations and the Ordovician Seydişehir and Bedinan formations, respectively (Bozdoğan \& Ertuğ 1997; Dean 2006).

The unconformably overlying Middle Devonian-early Carboniferous Zap Group is divided into the Yığınlı (Middle-Late Devonian) and Köprülü (early Carboniferous) formations (e.g. Gourvennec \& Hoşgör 2012). The Group is unconformably overlain by the Late Permian Gomaniibrik Formation (Y1lmaz \& Duran 1997).
The new fossil crinoid specimen is from the Yığınlı Formation, which was named by Açıkbaș (1978). In the northern and southern flanks of the Büyük Zap Anticline, the thickness of this formation varies between 200 and 270 metres, respectively. Overall the formation is brick-red colored arenites, dolomites, and grey to greenish mud- and siltstones (Yalçın \& Yılmaz 2010). In the southerly located Çukurca anticline, five informal members were recognised (e.g. Higgs et al. 2002). From bottom to the top these members are: 1) brown dolomites alternating with red shales representing carbonate intertidal flats and a muddy coastal plain; 2) pink quartz-sandstones and grey shales of fluvial-wave influenced deltaic environment; 3) red sandstones and siltstones with upward thinning sequences, which represent continental fluvial deposits; 4) Tidal-wave influenced grey sandstones and grey siltstones/ shales including echinoderms; and 5) alternation of grey mudstones with thin dolomites and limestones characterizing a carbonate-dominated complex of intertidal, shoreline, and marine shelf environments (Higgs et al. 2002). This new juvenile crinoid reported here is from the lower part of Member 5 of the Yığınlı Formation (Fig. 2). The small slab containing this new juvenile also contains brachiopods, bryozoans, and other crinoid columnals.

The overlying Köprülü Formation consists mainly of shallow marine carbonates and includes three informal members (Hoşgör et al. 2014). The lower member, representing a transgressive phase above the Yığınlı Formation, is dark grey and light pink silty and sandy limestones. The lower part of this member includes a fish fauna (Janvier et al. 1984) and corals (Denayer \& Hoşgör 2014). Stratigraphically above is an alternation of thinly laminated, dark gray, calcareous shales and siltstones with gray limestone interbeds of the middle member with bivalves and cephalopod remains (Hoşgör et al. 2014). The upper part of this member characteristically includes carbonate concretions. The upper member of the Köprülü Formation is a sequence of massive grey limestones with dolomitic interbeds.

In previous studies, the upper part of the Yığınlı Formation was dated by the aid of fish remains indicating a latest Devonian (Strunian) age (Janvier et al. 1984). More recently, miospore taxa suggesting a Famennian age have been reported from the same strata in the upper part of the Yığınlı Formation in the southern Çukurca anticline (Higgs et al. 2002). The Middle Devonian (upper Givetian) brachiopods reported by Gourvennec \& Hoşgör (2012) from the upper middle part (Member 4 of Higgs et al. 2002) provided evidence for an even earlier deposition age for the formation.

Just above the boundary-dolomite in the Middle Member of the Köprülü Formation, Hoşgör et al. (2014) reported bivalves of Tournaisian age and more recently rugose corals (Denayer \& Hoşgör 2014) of Tournaisian age. Thus, the D-C boundary was put within the boundary-dolomite (e.g. Hoşgör et al. 2014).

On the basis of the lithostratigraphic correlation and new biostratigraphic data, the location of the juvenile crinoid bearing sample is from the lower part of Member 5 (Higgs et al. 2002) and is constrained to the Famennian. 

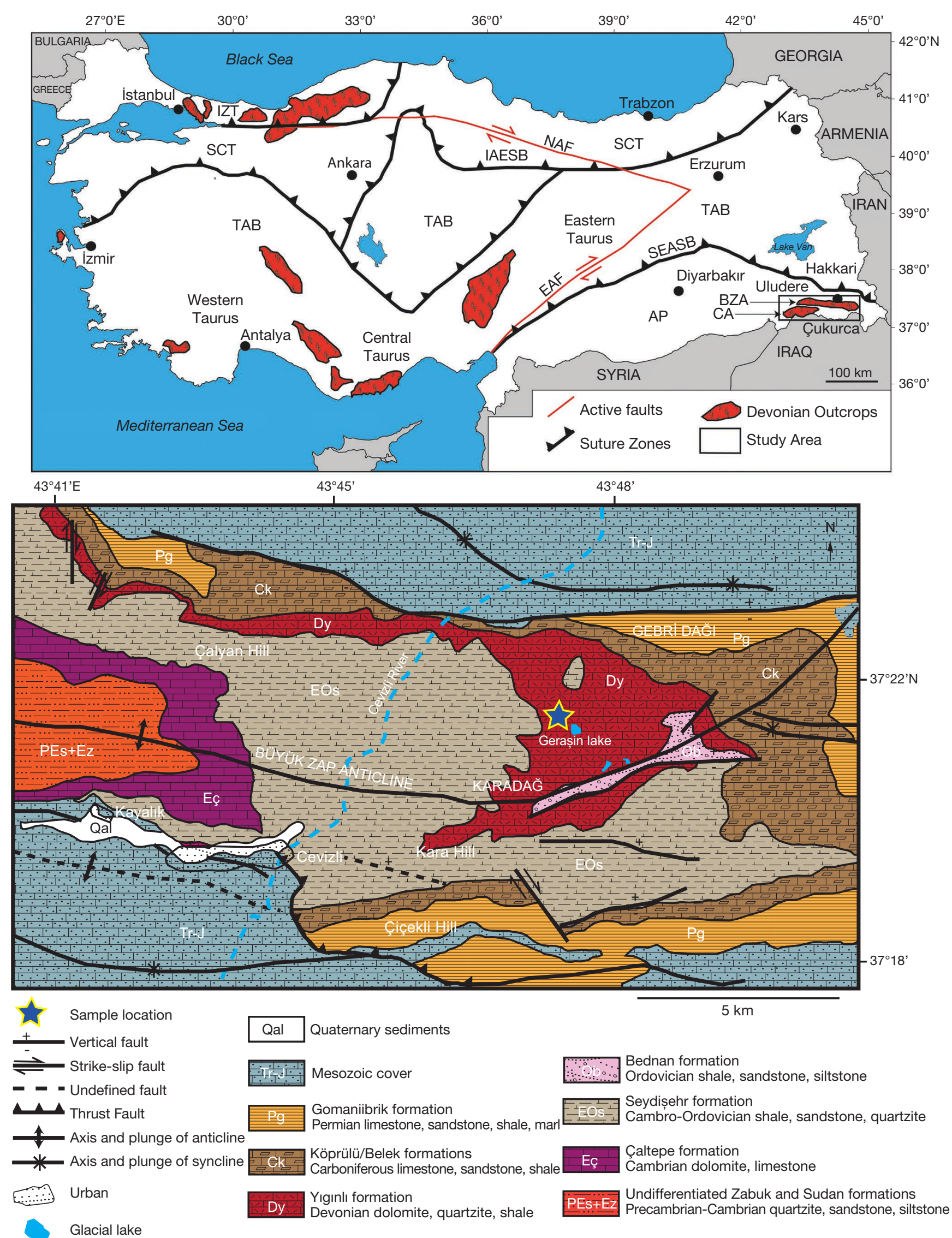

FIG. 1. - Distribution of Devonian units in Turkey (after Göncüoğlu 1997): A, tectonic map of Turkey with Devonian outcrops indicated; B, geological map (after Şenel 2002) of the Büyük Zap Anticline with the location of the crinoid bearing sample. Abbreviations: AP, Arabian Platform; BZA, Büyük Zap Anticline; CA, Çukurca Anticline; IAESZ, Izmir-Ankara-Erzincan Suture Zone; IZZ, Istanbul-Zonguldak Terrane; NAF, North Anatolian Fault; SEASB, Southeast Anatolian Suture Belt; SCT, Sakarya Composite Terrane; TAB, Tauride-Anatolide Belt. 


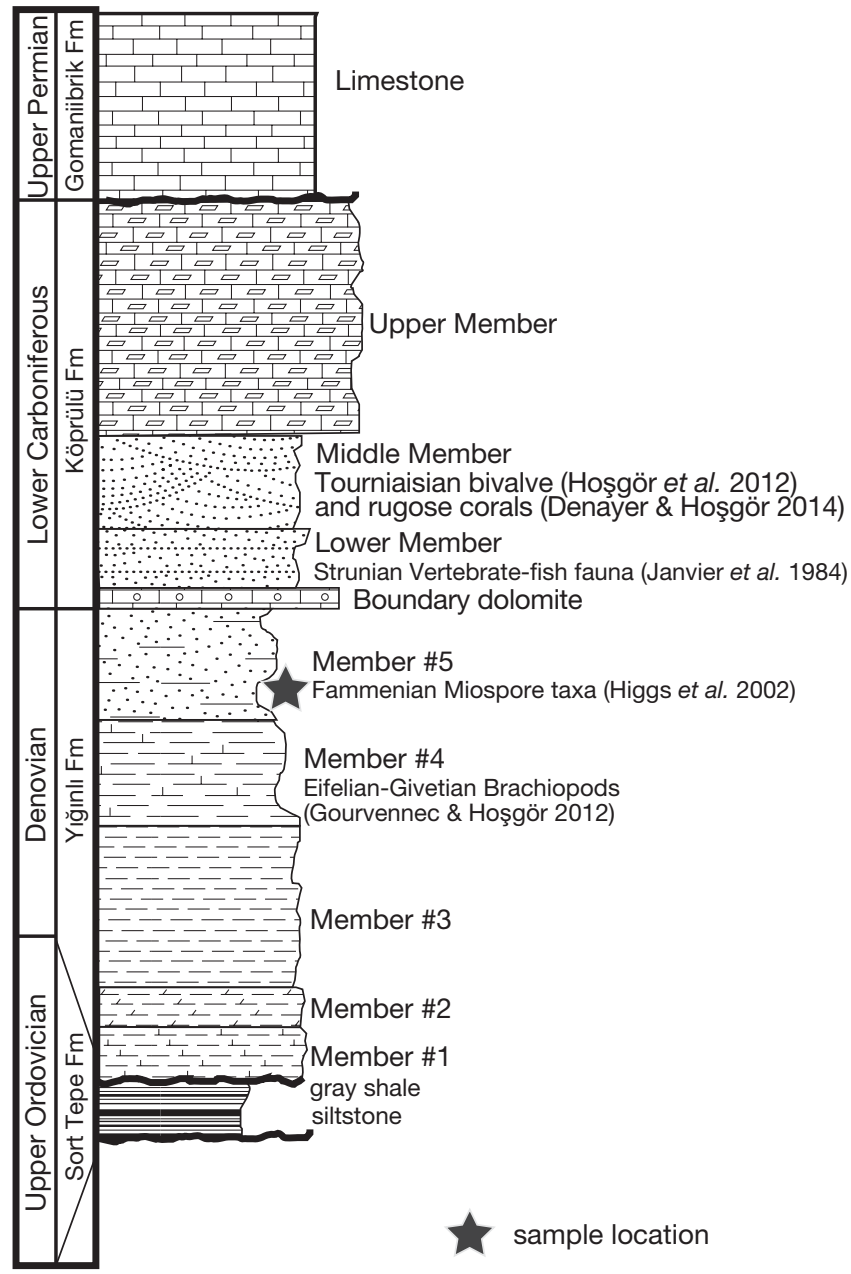

FIG. 2. - Generalized columnar section of Devonian-Lower Carboniferous units in the study area (modified after Higgins et al. 2002; Hoşgör et al. 2014). For lithological details see text.

\section{MATERIAL AND METHODS}

\section{ANATOMICAL TERMINOLOGY}

Morphological terminology follows Ubaghs (1978) and Ausich et al. (1999), with modifications from Ausich (1998) and Ausich et al. (2015). All measurements are in mm. Specimens are photographed after whitened with $\mathrm{NH} 4 \mathrm{Cl}$.

$\begin{array}{ll}\begin{array}{l}\text { Measurement abbreviations } \\ \text { ACH }\end{array} & \text { aboral cup height; } \\ \text { ACdW } & \text { aboral cup distal width; } \\ \text { ACpW } & \text { aboral cup proximal width; } \\ \text { AH } & \text { arm height; } \\ \text { ASH } & \text { anal sac height; } \\ \text { BH } & \text { basal plate height; } \\ \text { BW } & \text { basal plate width; } \\ \text { CoH } & \text { column height; } \\ \text { CrH } & \text { crown height; } \\ \text { IH } & \text { infrabasal circlet height; } \\ \text { RH } & \text { radial plate height; } \\ \text { RW } & \text { radial plate width. }\end{array}$

Institutional abbreviations

METU Geology Museum, Department Geological Engineering, Middle East Technical University, Ankara.

\section{PHYLOGENETIC POSITION}

The classification used here follows the phylogeny-based revision of crinoid higher taxa by Wright et al. (2017). Recent phylogenetic analyses have Camerata sister to the Cladida, with hybocrinids nested within the Cladida and sister to the porocrinids (Ausich et al. 2015; Wright 2017). Disparids and hybocrinids belong to the infraclass Inadunata, within the subclass Pentacrinoidea (Wright et al. 2017).

\section{SYSTEMATIC PALEONTOLOGY}

Class CRINOIDEA Miller, 1821

Parvclass CLADIDA Moore \& Laudon, 1943

Magnorder EUCLADIDA Wright, 2017

Family DENDROCRINIDAE Wachsmuth \& Springer, 1886

Genus and species indet.

MATERIAL. - METU-Geol Mus 2018-P1.

LOCALITY. - South of Geraşin glacial lake, Karadağ Mountain to the NE of Cevizli Village, Çukurca, Hakkari, southeastern Turkey $\left(37^{\circ} 21^{\prime} 56.64^{\prime \prime} \mathrm{N}, 43^{\circ} 47^{\prime} 45.14 \prime \mathrm{E}\right)$.

HORIZON AND AGE. - Yığınlı Formation, lower part of Member 5; Late Devonian (Famennian)

MeAsurements (in $\mathrm{mm}$; ${ }^{*}$, indicates an incomplete measurement or a crushed specimen). - $\mathrm{CrH}, 10.7 ; \mathrm{ACH}, 2.14$; ACpW, 0.3; ACdW, 2.9*; ICH, 0.42; BH, 0.64; BW, 0.57; RH, 0.79; RW, 0.86; $\mathrm{AH}, 9.7 ; \mathrm{ASH}, 8.4 ; \mathrm{CoH}, 7.1$.

\section{DESCRIPTION AND COMPARISON}

Very small crown, conical (Fig. 3). Aboral cup medium cone shaped, width to height ratio approximately 1.3 (with cup compacted), plates gently convex, surface texture of plates not preserved.

Infrabasal circlet approximately $23 \%$ of aboral cup height, base truncate; individual infrabasal plates not defined. Basal circlet approximately $35 \%$ of aboral cup height; non-CD interray basal plates, hexagonal, approximately as high as wide, smaller than radials. Radial circlet approximately $42 \%$ of aboral cup height; as known radial plates pentagonal, approximately 1.1 times wider than as high (Fig. 4). Radial facets probably peneplenary, planate.

Anal plates unknown. Central portion of preserved crown characterized by many, poorly defined, irregularly shaped small polygons that may represent the anal sac. This structure is nearly as high as the arms, tapers distally to a rounded shape.

Arms branch once, as known, in what appears to be an isotomous division. All brachials higher than wide or much higher than wide, 4 or more primibrachials. All brachials rectangular uniserial, aborally convex (Fig. 4).

Column circular, heteromorphic, holomeric; proxistele columnals wider than high; latus convex; mesistele columnals more equidimensional with straight latus (Fig. 3); other details of column unknown. 


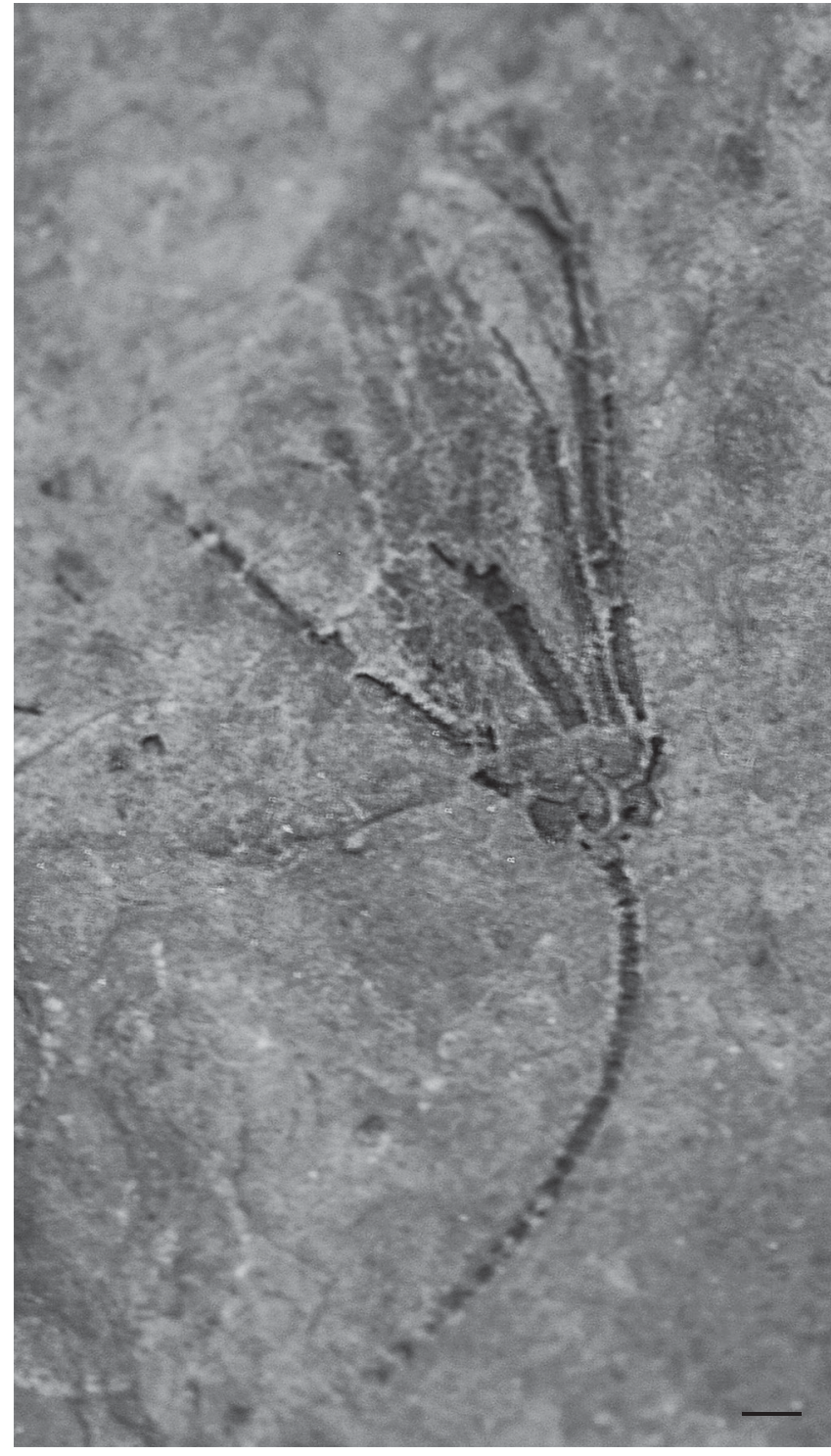

FIG. 3. - Photograph of Dendrocrinidae? gen., sp. indeterminate. Specimen coated with ammonium chloride. Scale bar: $1.0 \mathrm{~mm}$.

\section{DISCUSSION}

Key morphological features needed to diagnose this crinoid, such as the posterior interray plating and complete arm branching pattern, are not known in this new juvenile specimen. Further, the shape of the brachials, shape of the aboral cup, and relative heights of aboral cup plates would be expected to change through growth. It is possible that this new specimen belongs to the Dendrocrinidae. However, without a clear understanding of all diagnostic characters, the taxonomic affinities of this specimen cannot be determined with precision.

Both the very small size and brachial plates that are much higher than wide indicated that this new specimen is a juvenile. Juvenile crinoids are relatively rare, undoubtedly due to the small size, thin plates, and typically poorly sutured calyx plates. Most juvenile crinoid specimens known are

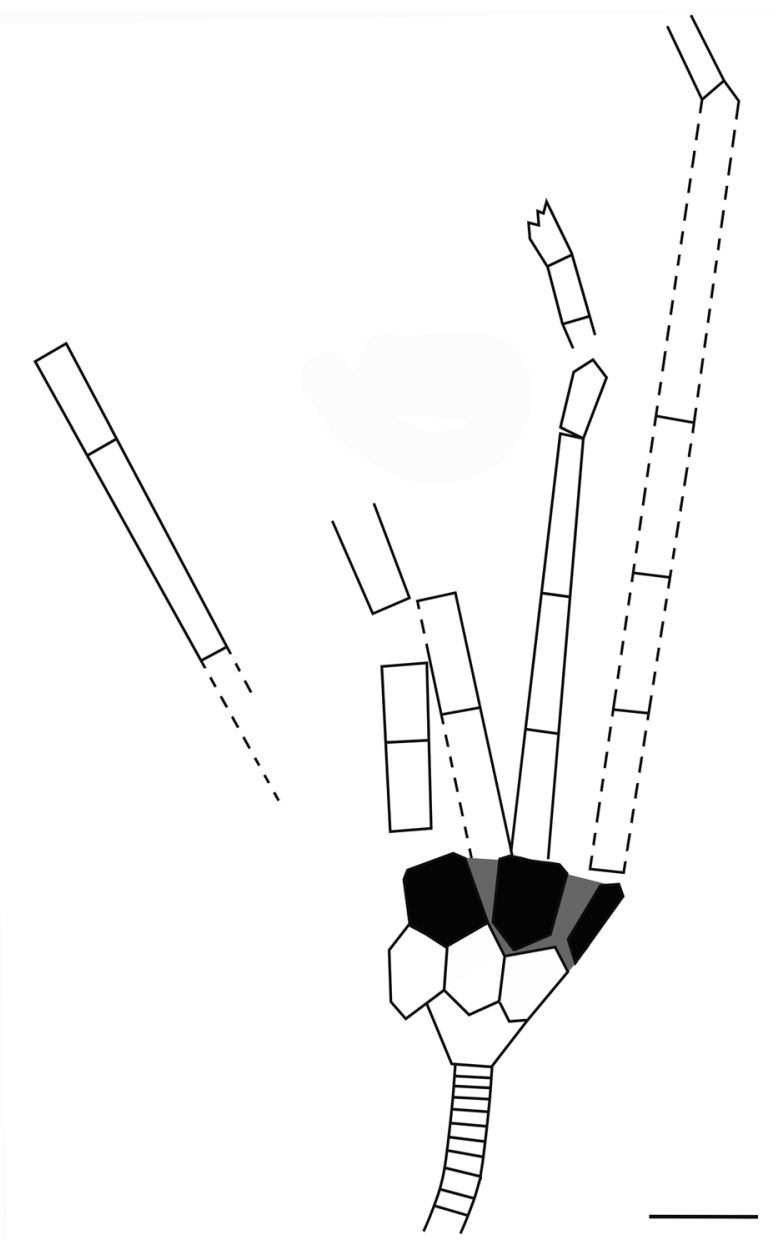

FIG. 4. - Plate diagram of Dendrocrinidae? gen., sp. indet. Black, radial plates; grey, matrix; Scale bar: $1.0 \mathrm{~mm}$.

microcrinoids, which are specimens with an aboral cup height less than or equal to $2.0 \mathrm{~mm}$ (Lane \& Sevastopulo 1982a, b; Sevastopulo \& Lane 1988). Growth series are known in many examples with the $2 \mathrm{~mm}$ height reached at a stage immediately after the radial facets form.

In striking contrast to typical microcrinoids, this new specimen is at a much more advanced growth stage. With the aboral cup c. $2.0 \mathrm{~mm}$ in height, arms are present through at least the secundibrachials, and the column is at least $3.0 \mathrm{~mm}$ in height. Although relatively few examples are known, juveniles of Paleozoic eucladids at approximately the comparable growth stage are much larger. Ausich \& Wood (2012) described a juvenile Hypselocrinus hoveyi (Worthen, 1875) (Mississippian eucladid). This juvenile had a higher aboral cup (c. $4.0 \mathrm{~mm}$ ), and pinnules had begun to develop. Compared to the specimen form Turkey, the $H$. hoveyi juvenile had a lower height:width ratio of the brachial plates. Although different in many ways, both the Mississippian and Devonian juveniles have a gradient of columnal heights from very short proximally to higher distally. The smallest Pennsylvanian juvenile eucladids reported by Peters $\&$ Lane (1990) also had an aboral cup height of $c .4 .0 \mathrm{~mm}$ 
and arm bifurcations above the first primibrachial. Again, this crinoid had a lower height:width ratio of the brachial plates than the Turkish specimen reported here. Amemiya et al. (2014: fig. 7E) illustrated a juvenile of the extant crinoid Metacrinus rotundus with an aboral cup height of c. $1.5 \mathrm{~mm}$. This extant juvenile has a broader aboral cup, pinnules present on the second primibrachial, and more robust columnals.

In summary, this new juvenile from Turkey adds to our understanding of development in fossil crinoids but confirms that our understanding of the full spectrum of eucladid postlarval growth remains poorly understood.

\section{CONCLUSIONS}

A key to understanding homologies in echinoderms is study of early post-larval development (Lane \& Sevastopulo 1982a, b; Sevastopulo \& Lane 1988; Ausich 1996; Wright 2015). However, very few Paleozoic crinoids are known from this early developmental stage. The new specimen reported herein from the Devonian (Famennian) of Turkey is at an advanced morphology for its size, which is in the microcrinoid size range. If the morphology of this Devonian crinoid is typical for eucladid crinoids, it is possible that the typical microcrinoids are neotenic. More very small juveniles are needed to confirm this hypothesis.

Crinoids have multi-element mesodermal skeletons in which the individual plates are held together during life with ligamentary tissue, muscular tissue, or both. These connective tissues decay rapidly after death (Meyer 1971; Liddell 1975), so a complete crinoid must have been permanently buried when alive (Donovan 1991; Taylor \& Brett 1996; Ausich 2001, 2016). The nearly complete preservation of the very small and delicate specimen described here indicates that depositional conditions existed favoring crinoid preservation during the Devonian of Turkey. Thus, a targeted search for additional fossils should yield more complete or nearly complete fossil crinoid specimens in the Devonian of Turkey.

\section{Acknowledgements}

The authors gratefully acknowledge Prof. Dr Nilgün Kazancı (Hacettepe University, Department of Biology) and Mr Necati Kazanc1 (Middle East Technical University) for donating the fossiliferous sample to the Geology Museum, Department of Geological Engineering, Middle East Technical University, in Ankara, Turkey. Mr Alican Aktag kindly helped with drawings. The authors acknowledge P. Gorzelak and D. F. Wright for their reviews that improved this manuscript.

\section{REFERENCES}

AÇIKBAȘ D. 1978. - Geology and Hydrocarbon Potential of the Çukurca, Köprülü, Yiğınlı (Hakkari Province) Area. MSc thesis, Department of Geological Engineering, Istanbul University, $52 \mathrm{p}$.
Amemiya S., Omori A., Tsurugaya T., Hibino T., Yamaguchi M., Kuraishi R., Kiyomoto M. \& Minokawa T. 2014. Early stalked stages in ontogeny of the living isocrinus sea lily Metacrinus rotundus. Acta Zoologica 97: 955-964. https://doi. org/10.1111/azo.12109

ARTHABer G. V. 1900. — Das jüngere Paläozoicum aus der AraxesEnge bei Djulfa, in Frech F. \& Arthaber G. V. (eds), Über das paläozoicum in Hocharmenien und Persien, Part IV. Beiträge Paläontologie, Geologie Österreich-Ungarns und Orients 12 (2): 209-302. https://www.biodiversitylibrary.org/page/14505906

Ausich W. I. 1996. - Crinoid plate circlet homologies. Journal of Paleontology 70: 955-964. https://doi.org/10.1017/ S0022336000038658

Ausich W. I. 1998. — Phylogeny of Arenig to Caradoc crinoids (Phylum Echinodermata) and suprageneric classification of the Crinoidea. University of Kansas Paleontological Contributions Papers, New series 9: 36 p. https://doi.org/10.17161/ PCNS.1808.3772

AusiCH W. I. 2001. - Echinoderm taphonomy, in LAWRENCE J. \& Jangoux M. (eds), Echinoderm Studies 6. Balkema Press, Rotterdam: $171-227$.

Ausich W. I. 2016. - Fossil species as data: A perspective from echinoderms, in Allmon W. D. \& YACOBUCCI M. M. (eds), Species and Speciation in the Fossil Record. University of Chicago Press, Chicago: 301-311. https://doi.org/10.7208/chicago/9780226377582.003.0011

Ausich W. I. \& WoOD T. E. 2012. - Ontogeny of Hypselocrinus hoveyi, Mississippian cladid crinoid from Indiana. Journal of Paleontology 86: 1017-1020. https://doi.org/10.1666/12-044R.1

Ausich W. I., Brett C. E., Hess H. \& Simms M. J. 1999. Crinoid form and function, in Hess H., Ausich W. I., BretT C. E. \& Simms M. J. (eds), Fossil Crinoids. Cambridge University Press, Cambridge, United Kingdom: 3-30. https://doi. org/10.1017/CBO9780511626159.003

Ausich W. I., Kammer T. W., Rhenberg E. C. \& Wright D. F. 2015. - Frontiers in Paleontology: Early phylogeny of crinoids within the Pelmatozoan clade. Palaeontology 58: 937-952. https://doi.org/10.1111/pala.12204

Ausich W. I., Wright D. F., Cole S. R. \& Sevastopulo G. D. 2020. - Homology of posterior interray plates in crinoids: A review and new perspectives from phylogenetics, the fossil record, and development. Palaeontology 2020: 1-21. https://doi.org/10.1111/pala.12475

BOZDOĞAN N. \& ERTUĞ K. 1997. - Geological evolution and paleogeography of the southeast Anatolia in the Paleozoic, in GÖNCÜOĞLU M. C. \& DeRman A. S. (eds), Paleozoic Evolution in NW Gondwana: Special Publication. Vol. 3. Turkish Association of Petroleum Geologists, Ankara: 39-49.

DEAN W. T. 2006. - Cambrian stratigraphy and trilobites of the Samur Dag Area, South of Hakkari, Southeastern Turkey. Turkish Journal of Earth Sciences 15: 225-257.

DenAYeR J. \& HoşGÖR I. 2014. - Lower Carboniferous Rugose Corals from the Arabian Plate: An insight from the Hakkari Area (SE Turkey). Journal of Asian Earth Sciences 79: 345-357. https://doi.org/10.1016/j.jseaes.2013.10.012

DONOVAN S. K. 1991. - The taphonomy of echinoderms: calcareous multi-element skeletons in the marine environment, in Donovan S. K. (ed.), The Process of Fossilization. Belhaven Press, London: 241-269.

GÖNCÜOĞLU M. C. 1997. — Distribution of Lower Paleozoic units in the Alpine Terranes of Turkey: Paleogeographic constrains, in GÖNCÜOĞLU M. C. \& DeRMAN A. S. (eds), Lower Paleozoic Evolution in Northwest Gondwana. Turkish Association of Petroleum Geolologists, Special Publication, Ankara, 3: 13-24.

GOURVENNEC R. \& HoşGÖR I. 2012. - New record of a MiddleDevonian brachiopod fauna from Southeastern Turkey (Y Y Formation, Zap Anticline, Çukurca-Hakkari). Bulletin of Geosciences 87 (2): 347-358. https://doi.org/10.3140/bull.geosci.1323 
Higgs T. D., Finucance D. \& Tunbridge I. P. 2002. — Late Devonian and early Carboniferous microfloras from the Hakkari Province of southeastern Turkey. Review of Palaeobotany and Palynology 118: 141-156. https://doi.org/10.1016/S0034-6667(01)00111-7

HoŞGÖR İ., OKAN Y. \& GÖNCÜOĞLU M. C. 2012. - Posidonia becheri Bronn, 1828 from the Tournaisian of SE Turkey: A palaeobiogeographic enigma. Comptes Rendus Palevol 11 (1): 13-20. https://doi.org/10.1016/j.crpv.2011.09.003

HoşGÖr I., Yilmaz I. O., Gourvennec R. \& Denayer J. 2014. Devonian to Basal Permian Lithostratigraphy in Southwestern Hakkari: A Perspective from Northern Arabian Mixed CarbonateSiliciclastic Platform, in International Conference \& Exhibition. Search and Discovery Article \#51050: 29 p.

Janvier P., Lethiers F., MONOD O. \& BALKAȘ Ö. 1984. — Discovery of a vertebrate fauna at the Devonian-Carboniferous boundary in SE Turkey (Hakkari Province). Journal of Petroleum Geology 7: 147-168. https://doi.org/10.1111/j.1747-5457.1984.tb00172.x

Lane N. G. \& SeVastopulo G. D. 1982a. - Microcrinoids from the Middle Pennsylvanian of Indiana. Journal of Paleontology 56 103-115. https://www.jstor.org/stable/1304496

Lane N. G. \& Sevastopulo G. D. 1982b. - Growth and systematic revision of Kallimorphocrinus astrus, a Pennsylvanian microcrinoid. Journal of Paleontology 56: 244-259. https://www. jstor.org/stable/1304512

LIDDELL W. E. 1975. - Recent crinoid taphonomy. Geological Society of America Abstracts with Programs 7: 1169.

MeYer D. L. 1971. - Post-mortem disintegration of Recent crinoids and ophiuroids under natural conditions. Geological Society of America Abstracts with Programs 3: 645-646.

Miller J. S. 1821. - A Natural History of the Crinoidea, or LilyShaped Animals; with Observations on the Genera. Asteria, Euryale, Comatula and Marsupites. Bryan \& Co., Bristol, England, Bryan \& Co., 150 p.

Moore R. C. \& LAUdOn L. R. 1943. - Evolution and classification of Paleozoic crinoids. Geological Society of America Special Paper 46: 151 p. https://doi.org/10.1130/SPE46

Peters J. \& LANe N. G. 1990. - Ontogenetic adaptations in some Pennsylvanian crinoids. Journal of Paleontology 64: 427-435. https://doi.org/10.1017/S0022336000018655

ŞENEL M. 2002. - 1/100.000 scaled Geological Maps of Turkey, Hakkari N51 Sheet. General Directorate of Mineral Research and Exploration, Publication 44: 40 p.

SeVASTOPUlO G. D. \& Lane N. G. 1988. - Ontogeny and phylogeny of disparid crinoids, in Paul C. R. C. \& SMith A. B. (eds), Echinoderm Phylogeny and Evolutionary Biology. Clarendon Press, Oxford: 245-253.

Sumrall C. D. \& Waters J. A. 2012. - Universal elemental homology for the peristome and ambulacra in blastozoan echinoderms. Journal of Paleontology 86: 956-972. https://doi. org/10.1666/12-029R.1
TAYLOR W. L. \& BRETT C. E. 1996. - Taphonomy and paleoecology of echinoderm Lagerstätten from the Silurian (Wenlockian) Rochester Shale. PALAIOS 26: 118-140. https://doi. org/10.2307/3515066

UBAGHS G. 1978. — Skeletal morphology of fossil crinoids, in MOORE R. C. \& Teichert K. (eds), Treatise on Invertebrate Paleontology, Echinodermata, Pt. T(2). Geological Society of America and University of Kansas Press, Boulder and Lawrence: T58-T216.

WaChSMUTH C. \& SPRINGER F. 1880-1886. - Revision of the Palaeocrinoidea: Proceedings of the Academy of Natural Sciences of Philadelphia Pt. I. The families Ichthyocrinidae and Cyathocrinidae (1880): 226-378 (https://www.biodiversitylibrary.org/ page/26289311) (separate repaginated: 1-153). Pt. II. Family Sphaeroidocrinidae, with the sub-families Platycrinidae, Rhodocrinidae, and Actinocrinidae (1881): 177-411 (https://www.biodiversitylibrary.org/page/6706896) (separate repaginated: 1-237). Pt. III, Sec. 1. Discussion of the classification and relations of the brachiate crinoids, and conclusion of the generic descriptions (1885): 225-364 (separate repaginated: 1-138). Pt. III, Sec. 2. Discussion of the classification and relations of the brachiate crinoids, and conclusion of the generic descriptions (1886): 64-226 (https://www.biodiversitylibrary.org/page/26302680) (separate repaginated to continue with section 1: 139-302).

Webster G. D., Yilmaz I. \& Kozlu H. 2008. — A new Middle Devonian gasterocomid crinoid from central Turkey and revision of the Gasterocomidae. Palaeoworld 17: 12-20. https://doi. org/10.1016/j.palwor.2007.12.001

Worthen A. H. \& Meek F. B. 1875. - Palaeontology of Illinois. Section II. Descriptions of invertebrates, in Geology and Palaeontology. Illinois Geological Survey 6 (2): 489-532.

Wright D. F. 2015. - Fossils, homology, and "Phylogenetic Paleo-ontogeny": a reassessment of primary posterior plate homologies among fossil and living crinoids with insight from developmental biology. Paleobiology 41: 570-591. https://doi org/10.1017/pab.2015.18

WRIGHT D. F. 2017. - Bayesian estimation of fossil phylogenies and the evolution of early to middle Paleozoic crinoids (Echinodermata). Journal of Paleontology 9: 799-814. https://doi. org/10.10.17/jpa.2-16.141

Wright D. F., Ausich W. I., Cole S. R., Peter M. E. \& RhenBERG E. C. 2017. - Phylogenetic taxonomy and classification of the Crinoidea (Echinodermata). Journal of Paleontology 91 829-846. https://doi.org/10.1917/jpa.2016.142

Yalçın M. N. \& Yilmaz I. 2010. — Devonian in Turkey - a review. Geologica Carphatica 61: 235-253. https://doi.org/10.2478/ v10096-010-0014-3

YiLMAZ E. \& DURAN O. 1997. - Nomenclature of autochthonous and allochthonous units in Southeastern Anatolia 'Lexicon'. Türkish Petroleum Corporation Research Centers Educational Series 31: $460 \mathrm{p}$. 